\title{
Methanothermococcus okinawensis sp. nov., a thermophilic, methane-producing archaeon isolated from a Western Pacific deep-sea hydrothermal vent system
}

Subground Animalcule Retrieval (SUGAR) Project, Frontier Research System for Extremophiles, Japan Marine Science \& Technology Center, 2-15 Natsushima-cho, Yokosuka 237-0061, Japan

\author{
Ken Takai, Akira Inoue and Koki Horikoshi \\ Author for correspondence: Ken Takai. Tel: +81468 67 3894. Fax: +81468666364. \\ e-mail: kent@jamstec.go.jp
}

\begin{abstract}
A novel thermophilic, methane-producing archaeon was isolated from a deepsea hydrothermal vent chimney at the lheya Ridge, in the Okinawa Trough, Japan. The cells were highly motile, irregular cocci, with a polar bundle of flagella. Growth was observed between 40 and $75^{\circ} \mathrm{C}$ (optimum 60-65 ${ }^{\circ} \mathrm{C}$; 30 min doubling time) and between pH 4.5 and 8.5 (optimum pH 6-7). The isolate was a strictly anaerobic autotroph capable of using hydrogen and carbon dioxide as sole sources of energy and carbon. Formate can serve as an alternative energy source. The $G+C$ content of the genomic DNA was $33.5 \mathrm{~mol} \%$. Phylogenetic analysis based on 165 rDNA sequences and DNA-DNA hybridization analysis indicated that the isolate was closely related to members of the genera Methanococcus and Methanothermococcus. This isolate, however, could be differentiated from the previously described species of these genera on the basis of its physiological and molecular properties. The name Methanothermococcus okinawensis sp. nov is proposed, with the type strain $\mathrm{IH1}^{\mathrm{T}}\left(=\mathrm{JCM} 11175^{\mathrm{T}}=\right.$ DSM $\left.14208^{\mathrm{T}}\right)$.
\end{abstract}

Keywords: deep-sea hydrothermal vent, thermophile, methanogen, Methanococcus, archaea

\section{INTRODUCTION}

Hyperthermophilic or thermophilic methanogens have been isolated from a variety of marine hydrothermal systems (Burggraff et al., 1990; Huber et al., 1982, 1989; Jeanthon et al., 1998, 1999; Jones et al., 1983b, 1989; Kurr et al., 1991; Stetter, 1996; Zhao et al., 1988 ) and sub-sea-floor oil reservoirs (Nilsen \& Torsvik, 1996; Orphan et al., 2000). Except for one isolate, Methanopyrus kandleri (Huber et al., 1989; Kurr et al., 1991), all of the methanogens isolated from marine hydrothermal vent systems and sub-sea-floor oil reservoirs are members of the order Methanococcales. Methanococcus thermolithotrophicus $\mathrm{SN}-1^{\mathrm{T}}$ and Methanococcus igneus $\mathrm{Kol} 5^{\mathrm{T}}$ were isolated from coastal hydrothermal systems of Italy and Iceland, respectively (Burggraff et al., 1990; Huber et al., 1982). Methanococcus jannaschii JAL-1 ${ }^{\mathrm{T}}$, Methanococcus vulcanius $\mathrm{M}^{\mathrm{T}}$, Methanococcus fervens $\mathrm{AG} 86^{\mathrm{T}}$ and Meth-

The GenBank/EMBL/DDBJ accession number for the $16 \mathrm{~S}$ rDNA sequence of strain $\mathrm{IH}^{\top}{ }^{\top}$ is $\mathrm{AB} 057722$. anococcus infernus $\mathrm{ME}^{\mathrm{T}}$ were isolated from deep-sea hydrothermal vent environments from the East Pacific Rise, Guaymas Basin and the Mid-Atlantic Ridge (Jeanthon et al., 1998, 1999; Jones et al., 1983b, 1989; Zhao et al., 1988). In addition, Methanococcus thermolithotrophicus ST22 and Methanococcus sp. strains vp183 and vp21, closely related to Methanococcus thermolithotrophicus $\mathrm{SN}-1^{\mathrm{T}}$, were isolated from deep sub-sea-floor oil reservoir waters in the North Sea (Nilsen \& Torsvik, 1996) and off the shore of California (Orphan et al., 2000). Based on their widespread occurrence, hyperthermophilic or thermophilic members of the Methanococcales are likely to be cosmopolitan micro-organisms inhabiting global marine hydrothermal vent systems and subsurface oil reservoir environments like the hyperthermophilic members of the order Thermococcales (L'Haridon et al., 1995; Slobodkin et al., 1999; Stetter et al., 1993; Takai et al., 2000; Zillig et al., 1983). However, no thermophilic methanogen has yet been cultivated from the hydrothermal vent systems located in the Western Pacific, although a number of microbiological surveys have 
been performed in hydrothermal vent fields in the Western Pacific.

Historically, the systematics of methanococci has been hindered by the absence of information on the reliability of phenotypic characters (Keswani et al., 1996). Based on the comparison of nearly complete $16 \mathrm{~S}$ rRNA sequences from the members of Methanococcus, Boone et al. (1993) recommended that the genus Methanococcus should be further subdivided into four genera to reduce the genetic diversity within one genus. More recently, Whitman et al. (2001) have proposed the creation of two families and four genera within the order Methanococcales. According to the newly proposed taxonomy, the mesophilic methanococci, including the as-yet undescribed 'Methanococcus aeolicus', belong to the genus Methanococcus and Methanococcus jannaschii, Methanococcus infernus, Methanococcus vulcanius and Methanococcus fervens belong to the genus Methanocaldococcus (Whitman et al., 2001). Methanococcus igneus is assigned to the genus Methanotorris and Methanococcus thermolithotrophicus to the genus Methanothermococcus (Whitman et al., 2001). This classification fits well the phylogenetic relationships associated with thermophily among the order Methanococcales recently provided by Keswani et al. (1996) and Jeanthon et al. (1999). However, both of the genera Methanotorris and Methanothermococcus are represented by single species and the phylogenetic affiliation of the deeply branched, mesophilic 'Methanococcus aeolicus' is still uncertain. Hence, additional isolates will be helpful in elucidating the phylogenetic organization and taxonomy of the order Methanococcales.

In this study, we succeeded in isolating a thermophilic methanogen from a deep-sea hydrothermal vent chimney at the Iheya Ridge, in the Okinawa Trough, Japan. Phylogenetic analysis revealed that the novel isolate is a member of the order Methanococcales. The novel isolate had physiological properties very similar to those of Methanothermococcus thermolithotrophicus, but it is more closely related phylogenetically to the mesophile 'Methanococcus aeolicus'. Based on its physiological properties and the results of DNA-DNA hybridization analysis, the isolate can be described as a novel species of Methanothermococcus that we have named Methanothermococcus okinawensis sp. nov.

\section{METHODS}

Sample collection. A sample from a deep-sea hydrothermal vent chimney was obtained from the hydrothermal field at Iheya Ridge in the Okinawa Trough, Japan $\left(27^{\circ} 47 \cdot 220^{\prime} \mathrm{N}\right.$, $\left.126^{\circ} 53.900^{\prime} \mathrm{E}\right)$ at a depth of $972 \mathrm{~m}$ by means of the manned submersible Shinkai 2000 in dive \#1194, performed in June 2000. This deep-sea hydrothermal vent site is the same site from which Thermosipho japonicus was isolated (Takai \& Horikoshi, 2000). The tip of the chimney was brought to the sea surface in a sample box.

Enrichment and purification. Immediately after the sample was retrieved from the submersible, portions of the fractured chimney were used to inoculate a series of media including
MMJ (described below) medium supplemented with $10 \mathrm{mM}$ sodium thiosulfate $\left(\mathrm{Na}_{2} \mathrm{~S}_{2} \mathrm{O}_{3} \cdot 5 \mathrm{H}_{2} \mathrm{O}\right)$ and $10 \mathrm{mM}$ magnetite $\left(\mathrm{Fe}_{3} \mathrm{O}_{4}\right)$ under a gas phase of $80 \% \mathrm{H}_{2}$ and $20 \% \mathrm{CO}_{2}$ $(300 \mathrm{kPa})$. The cultures were incubated at 70 and $85^{\circ} \mathrm{C}$ in dry ovens on-board ship. The bottles of MMJ medium incubated at $70^{\circ} \mathrm{C}$ became turbid after 2 days, but no growth was observed at $85^{\circ} \mathrm{C}$. To obtain a pure culture, the dilution-to-extinction technique was employed (Baross, 1995).

Sources of organisms. Methanococcus (Methanocaldococcus) jannaschii strain JAL- ${ }^{\mathrm{T}}$ (= JCM 10045 ${ }^{\mathrm{T}}$ ), Methanococcus (Methanothermococcus) thermolithotrophicus strain $\mathrm{SN}-1^{\mathrm{T}}$ $\left(=\mathrm{JCM} 10549^{\mathrm{T}}\right)$ and Methanococcus maripaludis strain $\mathbf{J J}^{\mathrm{T}}$ $\left(=\right.$ JCM $\left.10722^{\mathrm{T}}\right)$ were obtained from the Japan Collection of Microorganisms (JCM, Wako, Japan). All strains were cultivated under optimal conditions as described previously (Huber et al., 1982; Jones et al., 1983a, b).

Culture medium and conditions. The novel isolate was routinely cultivated in a standard medium, which was MMJ medium supplemented with $5 \mathrm{mM}$ calcium chloride $\left(\mathrm{CaCl}_{2}\right)$, $10 \mathrm{mM}$ sodium thiosulfate $\left(\mathrm{Na}_{2} \mathrm{~S}_{2} \mathrm{O}_{3} \cdot 5 \mathrm{H}_{2} \mathrm{O}\right)$ and $10 \mathrm{mM}$ magnetite $\left(\mathrm{Fe}_{3} \mathrm{O}_{4}\right)$. MMJ medium consisted of the following components ( $1^{-1} \mathrm{MJ}$ synthetic seawater): $1 \mathrm{ml}$ vitamin solution (Balch et al., 1979), $50 \mathrm{mg}$ sodium selenite, $30 \mathrm{mg}$ sodium tungstate, $1 \mathrm{mg}$ resazurin, $20 \mathrm{~g} \mathrm{NaHCO}_{3}, 0.5 \mathrm{~g}$ cysteine hydrochloride and $0.5 \mathrm{~g} \mathrm{Na}_{2} \mathrm{~S} .9 \mathrm{H}_{2} \mathrm{O}$ (Sako et al., 1996; Takai et al., 1999). To prepare the standard medium, $50 \mathrm{mg}$ sodium selenite, $30 \mathrm{mg}$ sodium tungstate and $1 \mathrm{mg}$ resazurin were dissolved in $11 \mathrm{MJ}$ synthetic seawater and the $\mathrm{pH}$ of the medium was adjusted to around $7 \cdot 0$ with $\mathrm{NaOH}$ before autoclaving. After autoclaving, a concentrated solution of vitamins (Balch et al., 1979), $\mathrm{NaHCO}_{3}$, thiosulfate, magnetite, cysteine hydrochloride ( $\mathrm{pH}$ adjusted to $7 \cdot 0$ ) and $\mathrm{Na}_{2} \mathrm{~S}$ ( $\mathrm{pH}$ adjusted to 7.0) were added to the medium. These solutions were sterilized separately by autoclaving except for the vitamin solution, which was filter-sterilized. The $\mathrm{pH}$ of the medium was adjusted with $\mathrm{H}_{2} \mathrm{SO}_{4}$ or $\mathrm{NaOH}$ in an anaerobic chamber under $90 \% \mathrm{~N}_{2}$ and $10 \% \mathrm{H}_{2}$ if needed. The medium was dispensed at $20 \%$ of the total bottle or tube volume and the tubes and bottles were sealed tightly with butyl rubber stoppers under a gas phase of $80 \% \mathrm{H}_{2}$ and $20 \% \mathrm{CO}_{2}$ at $300 \mathrm{kPa}$. In order to test the oxygen sensitivity of the isolate, the gas phase was replaced by a gas mixture of $80 \% \mathrm{H}_{2}, 15 \% \mathrm{CO}_{2}$ and $5 \% \mathrm{O}_{2}$ or $80 \% \mathrm{H}_{2}, 19 \% \mathrm{CO}_{2}$ and $1 \% \mathrm{O}_{2}$.

All experiments described below were conducted in duplicate. In an attempt to examine whether other potential electron donors and acceptors supported or stimulated growth in place of $\mathrm{H}_{2}$ and $\mathrm{CO}_{2}$, organic compounds such as yeast extract, peptone, tryptone, Casamino acids, amino acids, formate, acetate, methanol, ethanol, dimethyl sulfide and trimethylamine were tested in the presence or absence of $\mathrm{H}_{2}$ and $\mathrm{CO}_{2}$. The potential requirement for thiosulfate, magnetite, elemental sulfur, selenate, selenite, tungstate and nitrogen sources $\left(10 \mathrm{mM} \mathrm{NH} 4 \mathrm{Cl}, \mathrm{NaNO}_{2}\right.$ or $\mathrm{NaNO}_{3}$ ) for growth was also tested. To test the effect of $\mathrm{pH}$ on growth, the $\mathrm{pH}$ of $\mathrm{MMJ}$ medium was adjusted to various values with $10 \mathrm{mM}$ acetate/acetic acid buffer ( $\mathrm{pH} 4-5)$, MES (pH 5-6), PIPES ( $\mathrm{pH} \mathrm{6-7),} \mathrm{HEPES} \mathrm{(} \mathrm{pH} \mathrm{7-7 \cdot 5)} \mathrm{or} \mathrm{Tris} \mathrm{(} \mathrm{pH} \mathrm{8-9.5).}$ After autoclaving, the $\mathrm{pH}$ of the medium was checked and readjusted with $\mathrm{H}_{2} \mathrm{SO}_{4}$ or $\mathrm{NaOH}$ to the desired $\mathrm{pH}$ at room temperature. The $\mathrm{pH}$ was found to be stable during the cultivation period. To test the effect of the sea salts concentration on growth, MMJ medium was prepared with varying dilutions of $4 \times \mathrm{MJ}$ synthetic seawater $(1 \times \mathrm{MJ}$ synthetic seawater contains $30 \mathrm{~g} \mathrm{NaCl} \mathrm{l}^{-1}$ ). $\mathrm{H}_{2}$ and $\mathrm{CO}_{2}$ 
consumption and $\mathrm{CH}_{4}$ production during growth were measured by gas chromatography using a Micro GC CP2002 (GL Sciences).

Light and electron microscopy. Cells were routinely observed under visible, UV or blue light by phase-contrast microscopy using a Leica DMRB microscope with a Leica MPS 30 camera system. Transmission electron microscopy of negatively stained cells was carried out as described by Zillig et al. (1990). Cells grown in MMJ medium at $62{ }^{\circ} \mathrm{C}$ in the midexponential phase of growth were negatively stained with $2 \%(\mathrm{w} / \mathrm{v})$ uranyl acetate and observed under a JEOL JEM1210 electron microscope at an accelerating voltage of $80 \mathrm{kV}$.

Measurement of growth. Growth of the novel isolate was measured by direct cell counting after staining with $4^{\prime}, 6-$ diamidino-2-phenylindole (Porter \& Feig, 1980) using a Nikon Optiphot microscope. Cultures were prepared in duplicate. The cultures were grown in $100 \mathrm{ml}$ glass bottles (Schott Glaswerke), each containing $20 \mathrm{ml}$ medium, with shaking (200 r.p.m.) in a temperature-controlled dry oven. The $\mathrm{pH}$ growth curve was determined at $62^{\circ} \mathrm{C}$ and the growth conditions for all other cultivation tests were $62^{\circ} \mathrm{C}$

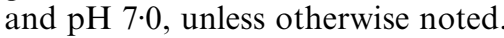

Susceptibility to antibiotics and lysis. Sensitivity of strain $\mathrm{IH} 1^{\mathrm{T}}$ to chloramphenicol $\left(50,100\right.$ and $\left.200 \mu \mathrm{g} \mathrm{ml}^{-1}\right)$, streptomycin $\left(100\right.$ and $\left.200 \mu \mathrm{g} \mathrm{ml}^{-1}\right)$, kanamycin $(100$ and $200 \mu \mathrm{g}$ $\left.\mathrm{ml}^{-1}\right)$, ampicillin $\left(100\right.$ and $200 \mu \mathrm{g} \mathrm{ml}^{-1}$ ) and rifampicin (50 and $100 \mu \mathrm{g} \mathrm{ml}^{-1}$ ) was tested at $62^{\circ} \mathrm{C}$. A simultaneous experiment was performed with Methanothermococcus thermolithotrophicus $\mathrm{SN}-1^{\mathrm{T}}$ at the same temperature. Susceptibility to lysis by SDS and by hypotonic solutions was tested as described previously (Boone \& Whitman, 1988).

Isolation and base composition of DNA. DNA was prepared as described by Marmur \& Doty (1962). The G+C content of the DNA was determined by direct analysis of deoxyribonucleotides by HPLC (Tamaoka \& Komagata, 1984). Non-methylated DNA from bacteriophage $\lambda(49.8 \mathrm{~mol} \%$ $\mathrm{G}+\mathrm{C}$; TaKaRa) (Sanger et al., 1982) was used as a reference.

Amplification of the 16S rRNA gene and sequence determination. The 16S rRNA gene (rDNA) was amplified by PCR using primers Arch21F and 1492R (DeLong, 1992; Lane, 1985). The $1.5 \mathrm{~kb}$ PCR product was sequenced directly by the dideoxynucleotide chain-termination method using a DNA sequencer model 377 (Perkin Elmer/Applied Biosystems). The rDNA sequence was analysed using the gapped-BLAST search algorithm (Altschul et al., 1997; Benson et al., 1998) to estimate the degree of similarity to other archaeal 16S rDNA sequences.

Data analysis. The almost-complete sequence (1392 bp) of the $16 \mathrm{~S}$ rDNA of strain $\mathrm{IH}^{\mathrm{T}}$ was aligned manually to $16 \mathrm{~S}$ rDNA data from the RDP based on primary and secondary structure. Phylogenetic analyses were restricted to nucleotide positions that were unambiguously alignable in all sequences (Takai \& Horikoshi, 1999a, b; Takai \& Sako, 1999). Neighbour-joining analysis and maximum-likelihood analysis were accomplished using the PHYLIP package (version 3.5; obtained from J. Felsenstein, University of Washington, Seattle, WA, USA). Bootstrap analysis was used to provide confidence estimates for phylogenetic tree topologies.

DNA-DNA hybridization analysis. DNA-DNA hybridization was carried out at $42{ }^{\circ} \mathrm{C}$ for $3 \mathrm{~h}$ and was measured fluorometrically using photobiotin according to the method of Ezaki et al. (1989). Methanocaldococcus jannaschii JAL-
$1^{\mathrm{T}}$, Methanothermococcus thermolithotrophicus $\mathrm{SN}-1^{\mathrm{T}}$ and Methanococcus maripaludis $\mathrm{JJ}^{\mathrm{T}}$ were used as reference strains.

\section{RESULTS AND DISCUSSION}

\section{Enrichment and purification}

Growth of anaerobic, thermophilic methanogens from a black smoker chimney sample was observed in MMJ medium supplemented with $10 \mathrm{mM}$ sodium thiosulfate $\left(\mathrm{Na}_{2} \mathrm{~S}_{2} \mathrm{O}_{3} .5 \mathrm{H}_{2} \mathrm{O}\right)$ and $10 \mathrm{mM}$ magnetite $\left(\mathrm{Fe}_{3} \mathrm{O}_{4}\right)$ after 2 days incubation at $70^{\circ} \mathrm{C}$. Cells were highly motile, irregular cocci and were fluorescent when viewed under UV and blue light excitation by epifluorescence microscopy. To obtain a pure culture, the dilution-toextinction technique was employed. The culture in the tube showing growth at the highest dilution was designated strain $\mathrm{IH}^{\mathrm{T}} \quad\left(=\mathrm{JCM} \quad 11175^{\mathrm{T}}=\mathrm{DSM}\right.$ $\left.14208^{\mathrm{T}}\right)$ and investigated in detail.

\section{Morphology}

The cells were irregular cocci with a mean diameter of $1.0-1.5 \mu \mathrm{m}$ (Fig. 1). As observed by light microscopy, the cells were highly motile, and a polar bundle of flagella was observed by electron microscopy (Fig. 1). Cells occurred singly and in pairs in all phases of growth. Although the novel isolate was observed to have slightly smaller cells, its morphological features were similar to those of Methanothermococcus thermolithotrophicus $\mathrm{SN}-1^{\mathrm{T}}$ and 'Methanococcus aeolicus' (Table 1).

\section{Growth parameters}

The novel isolate grew only under strictly anaerobic culture conditions and was strongly sensitive to oxygen. The isolate was found to be an autotrophic

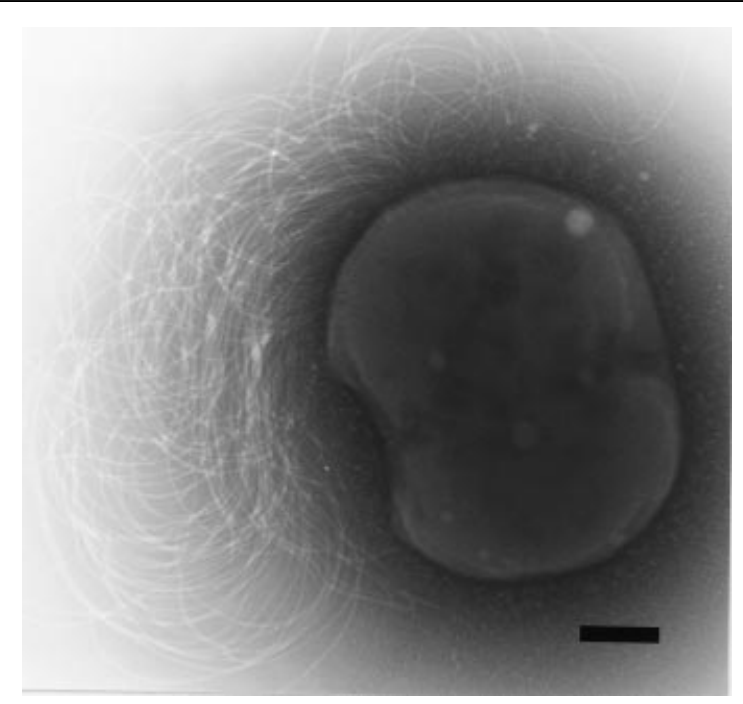

Fig. 1. Electron micrograph of negatively stained cells in the mid-exponential phase of growth. The polar bundle of flagella is observed. Bar, $400 \mathrm{~nm}$. 
Table 1. Comparison of properties between Methanothermococcus okinawensis sp. nov. and closely related strains

All three taxa use both $\mathrm{H}_{2} / \mathrm{CO}_{2}$ and formate as substrates for methane synthesis and use ammonium ions as a source of nitrogen. Data were taken from this study and from Huber et al. (1992) (Methanothermococcus thermolithotrophicus), Keswani et al. (1996) ('Methanococcus aeolicus') and Whitman et al. (2001) (both taxa).

\begin{tabular}{|c|c|c|c|}
\hline Character & $\begin{array}{l}\text { Methanothermococcus } \\
\text { okinawensis } \mathrm{IH1}^{\mathrm{T}}\end{array}$ & $\begin{array}{l}\text { Methanothermococcus } \\
\text { thermolithotrophicus } \mathrm{SN}-1^{\mathrm{T}}\end{array}$ & 'Methanococcus aeolicus' A \\
\hline Cell diameter $(\mu \mathrm{m})$ & $1 \cdot 0-1 \cdot 5$ & $1 \cdot 5$ & 1.7 \\
\hline \multicolumn{4}{|l|}{ Stimulatory for growth: } \\
\hline Selenium & + & ND & + \\
\hline Magnetite & + & $t^{*}$ & $\mathrm{ND}$ \\
\hline \multicolumn{4}{|l|}{ Nitrogen sources: } \\
\hline $\mathrm{N}_{2}$ & $\mathrm{ND}$ & + & + \\
\hline $\mathrm{NO}_{2}^{-}$ & - & ND & ND \\
\hline $\mathrm{NO}_{3}^{-}$ & - & + & $\mathrm{ND}$ \\
\hline Temperature range $\left({ }^{\circ} \mathrm{C}\right)$ & $40-75$ & $17-70$ & $<20-45$ \\
\hline Temperature optimum $\left({ }^{\circ} \mathrm{C}\right)$ & $60-65$ & $60-65$ & $\mathrm{ND}$ \\
\hline $\mathrm{pH}$ range & $4 \cdot 5-8 \cdot 5$ & $4 \cdot 9-9 \cdot 8$ & $6 \cdot 5-8 \cdot 0$ \\
\hline pH optimum & $6 \cdot 0-7 \cdot 0$ & $5 \cdot 1-7 \cdot 5$ & ND \\
\hline $\mathrm{NaCl}$ range $(\%, \mathrm{w} / \mathrm{v})$ & $0 \cdot 5-6 \cdot 0$ & $0 \cdot 6-9 \cdot 4$ & $1 \cdot 0->5 \cdot 0$ \\
\hline $\mathrm{NaCl}$ optimum $(\%, \mathrm{w} / \mathrm{v})$ & $1 \cdot 5-3 \cdot 0$ & $2 \cdot 0-4 \cdot 0$ & $1 \cdot 0-2 \cdot 0$ \\
\hline $\mathrm{G}+\mathrm{C}$ content of genomic DNA (mol \%) & 33.5 & 32.5 & 32 \\
\hline
\end{tabular}

* Checked in this study.

methanogen, utilizing $\mathrm{H}_{2}$ and $\mathrm{CO}_{2}$ as sole energy and carbon sources. During growth, $\mathrm{H}_{2}$ and $\mathrm{CO}_{2}$ in the headspace gas decreased and methane $\left(\mathrm{CH}_{4}\right)$ was produced (approx. 800 p.p.m. $\mathrm{H}_{2}, 8000$ p.p.m. $\mathrm{CO}_{2}$ and $90 \% \mathrm{CH}_{4}$ in the gas phase after 2 days incubation). The maximum cell yield with $\mathrm{H}_{2}$ and $\mathrm{CO}_{2}$ in the standard medium was obtained after 2 days incubation

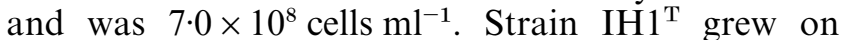
formate $(20 \mathrm{mM})$ in the absence of $\mathrm{H}_{2}(4.0 \times$ $10^{8}$ cells $\mathrm{ml}^{-1}$ after 2 days incubation), indicating that formate was an alternative energy source. Acetate $(20 \mathrm{mM})$, methanol $(0.05 \%, \mathrm{v} / \mathrm{v})$, ethanol $(0.05 \%$, $\mathrm{v} / \mathrm{v})$, dimethyl sulfide $(0 \cdot 2 \%, \mathrm{v} / \mathrm{v})$, trimethylamine $(0.2 \%, \mathrm{v} / \mathrm{v})$, yeast extract $(0.02 \%, \mathrm{w} / \mathrm{v})$, peptone $(0.02 \%, \mathrm{w} / \mathrm{v})$, tryptone $(0.02 \%, \mathrm{w} / \mathrm{v})$, Casamino acids $(0.02 \%, \mathrm{w} / \mathrm{v})$ and a mixture of 20 amino acids (containing $0.001 \%, \mathrm{w} / \mathrm{v}$, of each) did not support growth in the absence of $\mathrm{H}_{2}$ and did not stimulate growth in the presence of $\mathrm{H}_{2}$ and $\mathrm{CO}_{2}$. The novel isolate utilized ammonium ions as a nitrogen source but could not use nitrite or nitrate. The presence of magnetite $\left(\mathrm{Fe}_{3} \mathrm{O}_{4}\right)$ improved growth while thiosulfate $\left(\mathrm{S}_{2} \mathrm{O}_{3}\right)$ had no effect on growth and elemental sulfur $\left(\mathrm{S}^{0}\right)$ inhibited growth. Selenium was stimulatory to growth, while the novel isolate did not require tungsten for growth. The vitamin mixture was not required for growth.

The isolate grew over the temperature range $40-75^{\circ} \mathrm{C}$, showing optimal growth at $60-65^{\circ} \mathrm{C}$, and the generation time at $62^{\circ} \mathrm{C}$ was about $30 \mathrm{~min}$ at $\mathrm{pH} 7 \cdot 0$ (Fig. 2). No growth was observed at 30 or $80^{\circ} \mathrm{C}$. Growth of the novel isolate at $62{ }^{\circ} \mathrm{C}$ occurred between $\mathrm{pH} 4.5$ and $8 \cdot 5$, with optimum growth at about pH 6-7 (Fig. 2).
No growth was detected below $\mathrm{pH} 4 \cdot 5$ or above $\mathrm{pH} 8 \cdot 5$. The novel isolate required sea salts for growth. It grew over the concentration range $12-96$ g sea salts $1^{-1}$, with optimum growth at $25-50 \mathrm{~g}$ sea salts $1^{-1}$ at $62{ }^{\circ} \mathrm{C}$ and pH 7.0 (Fig. 2).

In many of its physiological properties, the novel isolate resembles Methanothermococcus thermolithotrophicus $\mathrm{SN}-1^{\mathrm{T}}$ (Huber et al., 1982). However, compared with Methanothermococcus thermolithotrophicus $\mathrm{SN}-1^{\mathrm{T}}$, the novel isolate has a slightly higher temperature range for growth and does not utilize nitrate as a sole nitrogen source (Table 1). In addition, thermophily was a significant physiological feature that differentiated the novel isolate from mesophilic Methanococcus species (Table 1).

\section{Sensitivity to antibiotics and lysis}

Methanothermococcus thermolithotrophicus $\mathrm{SN}-1^{\mathrm{T}}$ and the novel isolate showed the same antibiotic resistance pattern except for streptomycin. The novel isolate was resistant to streptomycin $\left(100 \mu \mathrm{g} \mathrm{ml}^{-1}\right)$. Cells of the novel isolate were lysed by $0.1 \%(\mathrm{w} / \mathrm{v})$ SDS and hypotonic solutions $\left[10^{-1}\right.$-diluted $\mathrm{MJ}(-\mathrm{N})$ synthetic seawater and distilled water].

\section{DNA base composition}

The $\mathrm{G}+\mathrm{C}$ content of the genomic DNA of strain $\mathrm{IH} 1^{\mathrm{T}}$ was found to be $33.5 \mathrm{~mol} \%$, which was slightly higher than those of Methanothermococcus thermolithotrophicus $\mathrm{SN}-1^{\mathrm{T}}$ and 'Methanococcus aeolicus' (Table 1). 


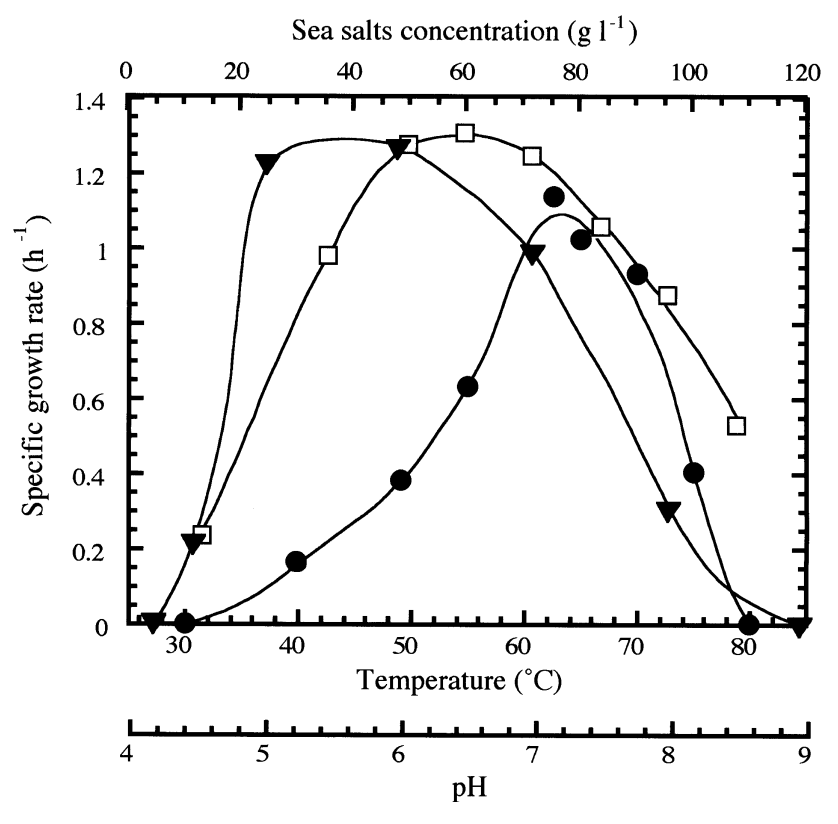

Fig. 2. Effects of temperature $(\bullet), \mathrm{pH}(\square)$ and sea salts concentration ( $\boldsymbol{\nabla})$ on growth of Methanothermococcus okinawensis sp. nov. Growth curves at different temperatures were determined in the standard medium at $\mathrm{pH} 7 \cdot 0$. The effect of $\mathrm{pH}$ on growth was determined in $\mathrm{MMJ}$ medium containing various buffers at $62^{\circ} \mathrm{C}$. The $\mathrm{pH}$ was adjusted at room temperature. The effect of sea salts concentration on growth was determined in varying dilutions of $4 \times M J$ synthetic sea water.

\section{Phylogenetic analyses and DNA-DNA hybridization}

The almost-complete sequence (1392 bp) of the 16S rRNA gene from strain $\mathrm{IH} 1^{\mathrm{T}}$ was determined. The
rDNA sequence of strain $\mathrm{IH}^{\mathrm{T}}$ was most closely related to those of members of the family Methanococcaceae (Whitman et al., 2001) such as 'Methanococcus aeolicus' (94.5\%) (Schmid et al., 1984; Keswani et al., 1996), Methanothermococcus thermolithotrophicus SN$1^{\mathrm{T}}$ (Huber et al., 1982) (94.8\%) and Methanococcus vannielii $\mathrm{SB}^{\mathrm{T}}(93.2 \%)$ (Stadtman \& Barker, 1951; Keswani et al., 1996). This result indicated that the novel isolate is a member of the family Methanococcaceae, represented by the genera Methanothermococcus and Methanococcus.

The neighbour-joining and maximum-likelihood methods yielded almost identical topologies, indicating that the novel isolate was phylogenetically related to 'Methanococcus aeolicus', while the sequence similarity of $16 \mathrm{~S}$ rDNA was almost the same with 'Methanococcus aeolicus' and Methanothermococcus thermolithotrophicus $\mathrm{SN}-1^{\mathrm{T}}$ (Fig. 3). Base composition disparities in the 16S rDNA sequences among Methanothermococcus and Methanococcus strains were relatively small (from a $\mathrm{G}+\mathrm{C}$ content of $54.3 \%$ in the Methanococcus voltae $\mathrm{PS}^{\mathrm{T}}$ DNA sequence to $57.2 \%$ in the Methanothermococcus thermolithotrophicus $\mathrm{SN}-1^{\mathrm{T}}$ rDNA sequence) (Fig. 3) and had little influence on the tree topology, supported by transversion distancematrix analysis (Woese et al., 1991). In addition, the bootstrap analysis revealed considerable confidence in the placement of $\mathrm{IH} 1^{\mathrm{T}}$ (Fig. 3).

Based on the phylogenetic analysis, the novel isolate was most closely related to 'Methanococcus aeolicus' (Schmid et al., 1984). This archaeon has not been validly described; however, DNA hybridization data and 16S rRNA sequence analysis suggested that it represents a novel species of the genus Methanococcus

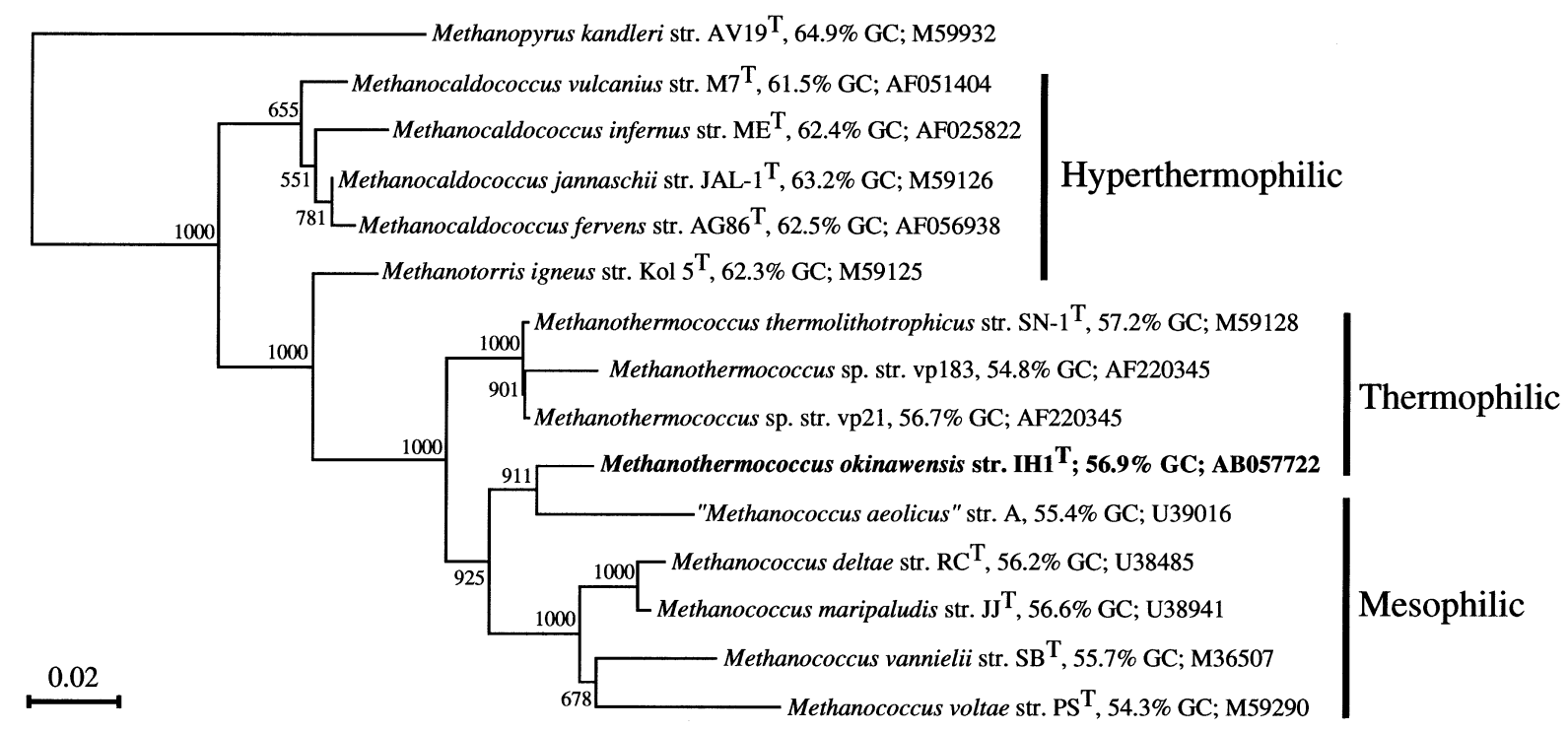

Fig. 3. Phylogenetic tree of representative members of the order Methanococcales inferred from 16S rDNA sequences by the neighbour-joining method using 689 homologous sequence positions for each organism. The numbers at each node represent bootstrap values (1000 replicates). Bar, 2 substitutions per 100 nucleotides. The $\mathrm{G}+\mathrm{C}$ content of the sequences analysed is given. 
(Keswani et al., 1996). In this study, we did not obtain this methanogen from public culture collections. Therefore, the DNA-DNA hybridization analysis was conducted among the novel isolate, Methanocaldococcus jannaschii JAL- $1^{\mathrm{T}}$, Methanothermococcus thermolithotrophicus $\mathrm{SN}-1^{\mathrm{T}}$ and Methanococcus maripaludis $\mathbf{J J}^{\mathrm{T}}$. The mean hybridization values comparing the novel isolate with Methanocaldococcus jannaschii JAL$1^{\mathrm{T}}$, Methanothermococcus thermolithotrophicus $\mathrm{SN}-1^{\mathrm{T}}$ and Methanococcus maripaludis $\mathrm{JJ}^{\mathrm{T}}$ were respectively $10 \cdot 7,17.6$ and $13.4 \%$. These results indicated that the novel isolate could be differentiated genotypically from the previously described species of the hyperthermophilic, thermophilic and mesophilic methanococci.

\section{Comparison with related species}

The phylogenetic analysis indicated that strain $\mathrm{IH} 1^{\mathrm{T}}$ was most closely related to 'Methanococcus aeolicus' (Schmid et al., 1984), which has not been validly described. According to Whitman et al. (2001), this methanogen is mesophilic, growing at temperatures between $<20$ and $45^{\circ} \mathrm{C}$ (Table 1 ). In addition, the cell size $(1.0-1.5 \mu \mathrm{m}$ diameter), $\mathrm{pH}$ range for growth $(4 \cdot 5-8 \cdot 5)$, optimal salinity for growth $(2-5 \%, \mathrm{w} / \mathrm{v})$ and $\mathrm{G}+\mathrm{C}$ content of the genomic DNA $(33.5 \mathrm{~mol} \%)$ differentiate the novel isolate from 'Methanococcus aeolicus' (Whitman et al., 2001) (Table 1). In many physiological properties, the novel isolate resembles Methanothermococcus thermolithotrophicus $\mathrm{SN}-1^{\mathrm{T}}$ (Huber et al., 1982) (Table 1). The slightly higher temperature range for growth and the inability to use nitrate as a sole nitrogen source may be physiological characteristics that separate them (Table 1). However, phylogenetic analysis based on $16 \mathrm{~S}$ rDNA and the DNA hybridization data clearly reveal that the novel isolate can be genetically differentiated from Methanothermococcus thermolithotrophicus $\mathrm{SN}-1^{\mathrm{T}}$ and other Methanothermococcus strains isolated from sub-seafloor oil reservoirs (Orphan et al., 2000), at least at the species level. On the basis of the physiological and genetic properties of the novel isolate, we propose that the isolate be classified as Methanothermococcus okinawensis sp. nov., and the type strain is $\mathrm{IH}^{\mathrm{T}}(=\mathrm{JCM}$ $11175^{\mathrm{T}}=$ DSM $\left.14208^{\mathrm{T}}\right)$.

\section{Description of Methanothermococcus okinawensis sp. nov.}

Methanothermococcus okinawensis (o.ki.na.wen'sis. N.L. adj. okinawensis of Okinawa, a region of Japan).

Irregular cocci, with a mean diameter of $1 \cdot 0-1 \cdot 5 \mu \mathrm{m}$. Cells occur singly or in pairs. Exhibits vigorous motility with a polar bundle of flagella. Strictly anaerobic and obligately methanogenic. The temperature range for growth is $40-75^{\circ} \mathrm{C}$, with the optimum being $60-65^{\circ} \mathrm{C}$. The $\mathrm{pH}$ range for growth is $4 \cdot 5-8 \cdot 5$, with optimum growth occurring at $\mathrm{pH} 6-7$. Sea salts are required for growth and the range is $12-96 \mathrm{~g}^{-1}$, with optimum growth occurring at $20-50 \mathrm{~g} \mathrm{l}^{-1}$. Growth occurs with $\mathrm{H}_{2}$ or formate as an electron donor and $\mathrm{CO}_{2}$ as an electron acceptor and a carbon source. Ammonium serves as a nitrogen source. Selenium and magnetite $\left(\mathrm{Fe}_{3} \mathrm{O}_{4}\right)$ are stimulatory for growth. Resistant to ampicillin $\left(200 \mu \mathrm{g} \mathrm{ml}^{-1}\right)$, kanamycin $\left(200 \mu \mathrm{g} \mathrm{ml}^{-1}\right)$, rifampicin $\left(100 \mu \mathrm{g} \mathrm{ml}^{-1}\right)$ and streptomycin $\left(200 \mu \mathrm{g} \mathrm{ml}^{-1}\right)$, but sensitive to chloramphenicol $\left(50 \mu \mathrm{g} \mathrm{ml}^{-1}\right)$. Cells are susceptible to lysis by $0 \cdot 1 \%(\mathrm{w} / \mathrm{v})$ SDS and hypotonic solutions. The $\mathrm{G}+\mathrm{C}$ content of genomic DNA is $33.5 \%$ (HPLC). The 16S rDNA sequence exhibits 94.8 and $94.5 \%$ similarity to those of Methanothermococcus thermolithotrophicus $\mathrm{SN}-1^{\mathrm{T}}$ and 'Methanococcus aeolicus'. The DNA-DNA relatedness to Methanocaldococcus jannaschii JAL- ${ }^{\mathrm{T}}$, Methanothermococcus thermolithotrophicus $\mathrm{SN}-1^{\mathrm{T}}$ and Methanococcus maripaludis $\mathrm{JJ}^{\mathrm{T}}$ is low.

The type strain, $\mathrm{IH}^{\mathrm{T}} \quad\left(=\mathrm{JCM} \quad 11175^{\mathrm{T}}=\mathrm{DSM}\right.$ $14208^{\mathrm{T}}$ ), was isolated from a deep-sea hydrothermal vent chimney at the Iheya Ridge, in the Okinawa Trough, Japan.

\section{ACKNOWLEDGEMENTS}

We would like to thank Dr Katsuyuki Uematsu for assistance in preparing electron micrographs. We are very grateful to the R/V Natsushima and Shinkai 2000 operation team for helping us to obtain deep-sea hydrothermal vent samples.

\section{REFERENCES}

Altschul, S. F., Madden, T. L., Schäffer, A. A., Zhang, J., Zhang, Z., Miller, W. \& Lipman, D. J. (1997). Gapped BLAST and PSI-BLAST: a new generation of protein database search programs. Nucleic Acids Res 25, 3389-3402.

Balch, W. E., Fox, G. E., Magrum, L. J., Woese, C. R. \& Wolfe, R. S. (1979). Methanogens: reevaluation of a unique biological group. Microbiol Rev 43, 260-296.

Baross, J. A. (1995). Isolation, growth, and maintenance of hyperthermophiles. In Archaea, a Laboratory Manual, Thermophiles, pp. 15-23. Edited by F. T. Robb \& A. R. Place. Cold Spring Harbor, NY: Cold Spring Harbor Laboratory.

Benson, D. A., Boguski, M. S., Lipman, D. J., Ostell, J. \& Ouellette, B. F. F. (1998). GenBank. Nucleic Acids Res 26, 1-7.

Boone, D. R. \& Whitman, W. B. (1988). Proposal of minimal standards for describing new taxa of methanogenic bacteria. Int J Syst Bacteriol 38, 212-219.

Boone, D. R., Whitman, W. B. \& Rouvière, P. (1993). Diversity and taxonomy of methanogens. In Methanogenesis: Ecology, Physiology, Biochemistry, and Genetics, pp. 35-80. Edited by J. G. Ferry. New York: Chapman \& Hall.

Burggraf, S., Fricke, H., Neuner, A., Kristjansson, J. K., Rouvier, P., Mandelco, L., Woese, C. R. \& Stetter, K. O. (1990). Methanococcus igneus sp. nov., a novel hyperthermophilic methanogen from a shallow submarine hydrothermal system. Syst Appl Microbiol 13, 33-38.

DeLong, E. F. (1992). Archaea in coastal marine environments. Proc Natl Acad Sci U S A 89, 5685-5689.

Ezaki, T., Hashimoto, Y. \& Yabuuchi, E. (1989). Fluorometric deoxyribonucleic acid-deoxyribonucleic acid hybridization in microdilution wells as an alternative to membrane filter hybridization in which radioisotopes are used to determine genetic relatedness among bacterial strains. Int J Syst Bacteriol 39, 224-229. 
Huber, H., Thomm, M., König, H., Thies, G. \& Stetter, K. O. (1982). Methanococcus thermolithotrophicus, a novel thermophilic lithotrophic methanogen. Arch Microbiol 132, 47-50.

Huber, R., Kurr, M., Jannasch, H. W. \& Stetter, K. O. (1989). A novel group of abyssal methanogenic archaebacteria (Methanopyrus) growing at $110^{\circ} \mathrm{C}$. Nature $\mathbf{3 4 2}, 833-834$

Jeanthon, C., L'Haridon, S., Reysenbach, A. L., Vernet, M., Messner, P., Sleytr, U. B. \& Prieur, D. (1998). Methanococcus infernus sp. nov., a novel hyperthermophilic lithotrophic methanogen isolated from a deep-sea hydrothermal vent. Int J Syst Bacteriol 48, 913-919.

Jeanthon, C., L'Haridon, S., Reysenbach, A.-L., Corre, E., Vernet, M., Messner, P., Sleytr, U. B. \& Prieur, D. (1999). Methanococcus vulcanius sp. nov., a novel hyperthermophilic methanogen isolated from East Pacific Rise, and identification of Methanococcus sp. DSM 4213 as Methanococcus fervens sp. nov. Int J Syst Bacteriol 49, 583-589.

Jones, W. J., Paynter, M. J. B. \& Gupta, R. (1983a). Characterization of Methanococcus maripaludis sp. nov., a new methanogen isolated from salt marsh sediment. Arch Microbiol 135, 91-97.

Jones, W. J., Leigh, J. A., Mayer, F., Woese, C. R. \& Wolfe, R. S. (1983b). Methanococcus jannaschii sp. nov., an extremely thermophilic methanogen from a submarine hydrothermal vent. Arch Microbiol 136 , 254-261.

Jones, W. J., Stugard, C. E. \& Jannasch, H. W. (1989). Comparison of thermophilic methanogens from submarine hydrothermal vents. Arch Microbiol 151, 314-318.

Keswani, J., Orkand, S., Premachandran, U., Mandelco, L., Franklin, M. J. \& Whitman, W. B. (1996). Phylogeny and taxonomy of mesophilic Methanococcus spp. and comparison of rRNA, DNA hybridization, and phenotypic methods. Int $J$ Syst Bacteriol 46, 727-735.

Kurr, M., Huber, R., König, H., Jannasch, H. W., Fricke, H., Trincone, A., Kristjansson, J. K. \& Stetter, K. O. (1991). Methanopyrus kandleri, gen. and sp. nov. represents a novel group of hyperthermophilic methanogens, growing at $110^{\circ} \mathrm{C}$. Arch Microbiol 156, 239-247.

Lane, D. J. (1985). 16S/23S rRNA sequencing. In Nucleic Acid Techniques in Bacterial Systematics, pp. 115-175. Edited by E. Stackebrandt \& M. Goodfellow. Chichester: Wiley.

L'Haridon, S., Reysenbach, A.-L., Glenat, P., Prieur, D. \& Jeanthon, C. (1995). Hot subterranean biosphere in a continental oil reservoir. Nature 377, 223-224.

Marmur, J. \& Doty, P. (1962). Determination of the base composition of deoxyribonucleic acid from its thermal denaturation temperature. $J$ Mol Biol 5, 109-118.

Nilsen, R. K. \& Torsvik, T. (1996). Methanococcus thermolithotrophicus isolated from North Sea oil field reservoir water. Appl Environ Microbiol 62, 728-731.

Orphan, V. J., Taylor, L. T., Hafenbradl, D. \& DeLong, E. F. (2000). Culture-dependent and culture-independent characterization of microbial assemblages associated with high-temperature petroleum reservoirs. Appl Environ Microbiol 66, 700-711.

Porter, K. G. \& Feig, Y. S. (1980). The use of DAPI for identifying and counting microflora. Limnol Oceanogr 25, 943-948.

Sako, Y., Takai, K., Ishida, Y., Uchida, A. \& Katayama, Y. (1996). Rhodothermus obamensis sp. nov., a modern lineage of extremely thermophilic marine bacteria. Int J Syst Bacteriol 46, 1099-1104.

Sanger, F., Coulson, A. R., Hong, G. F., Hill, D. F. \& Petersen, G. B. (1982). Nucleotide sequence of bacteriophage $\lambda$ DNA. J Mol Biol 162 , 729-773.
Schmid, K., Thomm, M., Laminet, A., Laue, F. G., Kessler, C., Stetter, K. O. \& Schmitt, R. (1984). Three new restriction endonucleases MaeI, MaeII and MaeIII from Methanococcus aeolicus. Nucleic Acids Res 12, 2619-2628.

Slobodkin, A. I., Jeanthon, C., L'Haridon, S., Nazina, T., Miroshnichenko, M. \& Bonch-Osmolovskaya, E. (1999). Dissimilatory reduction of $\mathrm{Fe}(\mathrm{III})$ by thermophilic bacteria and archaea in deep subsurface petroleum reservoirs of western Siberia. Curr Microbiol 39, 99-102.

Stadtman, T. C. \& Barker, H. A. (1951). Studies on the methane fermentation. X. A new formate-decomposing bacterium, Methanococcus vannielii. J Bacteriol 62, 269-280.

Stetter, K. O. (1996). Hyperthermophilic procaryotes. FEMS Microbiol Rev 18, 149-158.

Stetter, K. O., Huber, R., Blöchl, E., Kurr, M., Eden, R. D., Fielder, M., Cash, H. \& Vance, I. (1993). Hyperthermophilic archaea are thriving in deep North Sea and Alaskan oil reservoirs. Nature 365, 743-745.

Takai, K. \& Horikoshi, K. (1999a). Genetic diversity of archaea in deep-sea hydrothermal vent environments. Genetics 152, 1285-1297.

Takai, K. \& Horikoshi, K. (1999b). Molecular phylogenetic analysis of archaeal intron-containing genes coding for rRNA obtained from a deep-subsurface geothermal water pool. Appl Environ Microbiol 65, 5586-5589.

Takai, K. \& Horikoshi, K. (2000). Thermosipho japonicus sp. nov., an extremely thermophilic bacterium isolated from a deep-sea hydrothermal vent in Japan. Extremophiles 4, 9-17.

Takai, K. \& Sako, Y. (1999). A molecular view of archaeal diversity in marine and terrestrial hot water environments. FEMS Microbiol Ecol 28, 177-188.

Takai, K., Inoue, A. \& Horikoshi, K. (1999). Thermaerobacter marianensis gen. nov., sp. nov., an aerobic extremely thermophilic marine bacterium from the $11000 \mathrm{~m}$ deep Mariana Trench. Int J Syst Bacteriol 49, 619-628.

Takai, K., Sugai, A., Itoh, T. \& Horikoshi, K. (2000). Palaeococcus ferrophilus gen. nov., sp. nov., a barophilic, hyperthermophilic archaeon from a deep-sea hydrothermal vent chimney. Int J Syst Evol Microbiol 50, 489-500.

Tamaoka, J. \& Komagata, K. (1984). Determination of DNA base composition by reversed-phase high-performance liquid chromatography. FEMS Microbiol Lett 25, 125-128.

Whitman, W. B., Boone, D. R. \& Koga, Y. (2001). Order I. Methanococcales Balch and Wolfe 1981. In Bergey's Manual of Systematic Bacteriology, 2nd edn, vol. 1. The Archaea and The Deeply Branching and Phototrophic Bacteria, pp. 236-246. Edited by D. R. Boone, R. W. Castenholz \& G. Garrity. Berlin \& Heidelberg: Springer.

Woese, C. R., Achenbach, L., Rouviere, P. \& Mandelco, L. (1991). Archaeal phylogeny: reexamination of the phylogenetic position of Archaeoglobus fulgidus in light of certain composition-induced artifacts. Syst Appl Microbiol 14, 364-371.

Zhao, H., Wood, A. G., Widdel, F. \& Bryant, M. P. (1988). An extremely thermophilic Methanococcus from a deep-sea hydrothermal vent and its plasmid. Arch Microbiol 150, 178-183.

Zillig, W., Holz, I., Janekovic, D., Schafer, W. \& Reiter, W. D. (1983). The archaebacterium Thermococcus celer represents a novel genus within the thermophilic branch of the archaebacteria. Syst Appl Microbiol 4, 88-94.

Zillig, W., Holz, I., Janekovic, D. \& 7 other authors (1990). Hyperthermus butylicus, a hyperthermophilic sulfur-reducing archaebacterium that ferments peptides. J Bacteriol 172, 3959-3965. 